\title{
Emisja zanieczyszczeń do powietrza z procesów magazynowania i przeładunku substancji towarzyszących eksploatacji złóż ropy naftowej i gazu ziemnego
}

\begin{abstract}
Artykuł porusza problematykę obliczania wielkości emisji gazów cieplarnianych i innych zanieczyszczeń gazowych, wprowadzanych do powietrza w trakcie procesów magazynowania i przeładunku węglowodorów i metanolu w kopalniach ropy naftowej i gazu ziemnego. W oparciu o analizę stanu prawnego, a także uwarunkowania techniczne procesów magazynowania i transportu węglowodorów oraz ocenę możliwości zastosowania poszczególnych sposobów obliczania emisji, spośród dostępnych metod wskazane zostały takie, które pozwalają na poprawne obliczenie wprowadzanych do powietrza zanieczyszczeń.
\end{abstract}

Słowa kluczowe: emisja zanieczyszczeń, wskaźniki emisji.

\section{Emission of pollutants into the air from the processes of storage and handling of substances associated with oil and natural gas exploration}

\begin{abstract}
The article raises the problem of calculating the emissions of greenhouse gases and other gaseous pollutants released into the air, during the process of storage and handling of substances associated with the exploration of oil and natural gas deposits. Based on the analysis of the legislation in force and technical conditions of storage and transport, as well as the applicability of the available techniques of calculating emissions, the most accurate methods for the calculation of pollutants released into the air were identified.
\end{abstract}

Key words: emissions, emission factors.

\section{Wstęp}

Wydobycie węglowodorów oraz magazynowanie i przeładunek substancji chemicznych wykorzystywanych podczas tego procesu jest źródłem emisji zanieczyszczań gazowych i pyłowych do powietrza. Emisje te mogą pochodzić zarówno z procesów energetycznego spalania paliw w warunkach kontrolowanych, np. spalanie oleju napędowego w agregatach prądotwórczych wykorzystanych do napędu urządzenia wiertniczego, jak również przeładunku i tymczasowego magazynowania w zbiornikach kopaliny (ropy naftowej) lub innych substancji chemicznych stosowanych podczas procesu wydobycia kopaliny.

Zgodnie z art. 285 znowelizowanej Ustawy z dnia 27 kwietnia 2001 r. Prawo ochrony środowiska (Dz. U. z 2016 r., poz. 672 , ze zm.), która zacznie obowiązywać od 1 stycznia
2019 r., podmiot korzystający ze środowiska będzie wnosić opłatę za wprowadzanie gazów lub pyłów do powietrza w wysokości ustalonej na podstawie wielkości rocznej rzeczywistej emisji określonej w raporcie składanym do Krajowej bazy o emisjach gazów cieplarnianych i innych substancji, prowadzonej przez Krajowy Ośrodek Bilansowania i Zarządzania Emisjami (KOBIZE), o którym mowa w art. 7 Ustawy z dnia 17 lipca 2009 r. o systemie zarzadzania emisjami gazów cieplarnianych i innych substancji (Dz. U. z 2013 r., poz. 1107, ze zm.). Na podstawie informacji zawartych w raporcie składanym do KOBIZE sporządzany będzie wykaz obejmujący informacje o rodzajach substancji wprowadzanych do powietrza, wielkości emisji i wysokości opłat, przedkładany marszałkowi województwa. 
Ze względu na to, że w instalacjach technologicznych w zdecydowanej większości nie są prowadzone ciągłe pomiary monitoringowe emisji i nie jest możliwe wykorzystanie ich wyników do szacowania wielkości emisji, najczęściej wykorzystywaną metodą jest posługiwanie się wartościami wskaźnikowymi. Metoda ta jest metodą najprostszą i najtańszą, ale obarczoną dość dużym błędem. Stosowane do obliczania wielkości emisji wskaźniki nie są określone żadnym aktem prawnym, a dostępne w różnych opracowaniach wartości można traktować jako materiał pomocniczy.

\section{Pomiary emisji gazów lub pyłów do powietrza z instalacji lub urządzeń}

Prowadzący instalację, która emituje do środowiska gazy lub pyły i wymaga uzyskania pozwolenia na ich wprowadzanie do powietrza (lub pozwolenia zintegrowanego), ma obowiązek monitorowania emitowanych zanieczyszczeń. Obowiązek ten realizowany jest poprzez zapewnienie wykonania pomiarów wielkości emisji we wskazanym zakresie. Przypadki, w których wymagane są ciągłe lub okresowe pomiary emisji z instalacji lub urządzenia oraz częstotliwości prowadzenia pomiarów, określa Rozporządzenie Ministra Środowiska z dnia 30 października 2014 r. w sprawie wymagań w zakresie prowadzenia pomiarów wielkości emisji oraz pomiarów ilości pobieranej wody (Dz. U. z 2014 r., poz. 1542). Dokument ten określa również referencyjne metodyki wykonywana pomiarów oraz sposób ich ewidencjonowania. Zgodnie z § 2.1 wyżej wymienionego rozporządzenia ciągłe lub okresowe pomiary emisji do powietrza prowadzi się dla źródeł spalania paliw wymagających pozwolenia na wprowadzanie gazów lub pyłów do powietrza albo pozwolenia zintegrowanego, w tym źródeł spalania paliw, dla których określa się standardy emisyjne zgodnie z $§ 5$ ust. 1 Rozporzadzenia Ministra Środowiska z dnia 4 listopada 2014 r. w sprawie standardów emisyjnych dla niektórych rodzajów instalacji, źródet spalania paliw oraz urzadzeń spalania lub wspótspalania odpadów (Dz. U. z 2014 r., poz. 1546). Rodzaje wyników pomiarów wykonywanych w związku z eksploatacją instalacji lub urządzenia, które prowadzący instalację przekazuje organom ochrony środowiska, określa Rozporzadzenie Ministra Środowiska z dnia 19 listopada $2008 r$. w sprawie rodzajów wyników pomiarów prowadzonych $w$ zwiazku z eksploatacja instalacji lub urzadzenia i innych danych oraz terminów $i$ sposobów ich realizacji (Dz. U. z 2008 r. nr 215, poz. 1366). Obowiązki związane z pomiarem emisji mogą również zostać określone w pozwoleniu zintegrowanym lub pozwoleniu na wprowadzanie gazów lub pyłów do powietrza. Określa ono zakres i sposób monitorowania procesów technologicznych, w tym pomiarów i ewidencjonowania wielkości emisji w zakresie, w jakim wykraczają one poza wymagania podstawowe ustalone w rozporządzeniu.

Jak wynika z przytoczonych powyżej regulacji prawnych, procesy magazynowania lub przeładunku ropy naftowej, produktów naftowych, LPG lub CNG nie podlegają obowiązkowi przeprowadzania pomiarów emisji do powietrza, ponieważ nie wymagają uzyskania pozwolenia na wprowadzanie gazów lub pyłów do powietrza. Nie oznacza to jednak, że prowadzący taki rodzaj instalacji nie jest zobowiązany do określania emisji z procesu magazynowania i przeładunku wyżej wymienionych cieczy. Konieczność ustalenia wielkości emisji wynika m.in. z obowiązku wnoszenia opłat za korzystanie ze środowiska, w tym wypadku wprowadzania gazów lub pyłów do powietrza, a także raportowania do Krajowego Ośrodka Bilansowania i Zarządzania Emisjami (KOBiZE), w związku z realizacją zapisów ustawy o systemie zarządzania emisjami - Ustawa $z$ dnia 17 lipca 2009 r. o systemie zarzadzania emisjami gazów cieplarnianych i innych substancji (Dz. U. z 2015 r., poz. 2273, ze zm.). W przypadku raportowania emisji z magazynowania i przeładunku ropy naftowej, kondensatu (gazoliny), do którego zobowiązane są kopalnie ropy naftowej i gazu ziemnego, problemem jest wiarygodne określenie wielkości emisji (wiarygodne tzn. odpowiadające rzeczywistości, a więc także nieprzeszacowane).

\section{Charakterystyka emitorów i emisji}

Emisja zanieczyszczeń w trakcie procesu magazynowania substancji następuje na skutek tzw. „oddychania zbiorników", kiedy wtłaczana do zbiornika ciecz powoduje wzrost ciśnienia oparów powyżej nastawy zaworu oddechowego. Proces „oddychania” jest uwarunkowany istnieniem wolnej przestrzeni nad magazynowaną cieczą i możliwością wydostania się na zewnątrz mieszaniny parowo-powietrznej. Rozróżnia się tzw. „mały oddech” i ,duży oddech”.
„Mały oddech” występuje okresowo na skutek wzrostu ciśnienia wewnątrz zbiornika spowodowanego zmianami czynników meteorologicznych, tj. np. ciśnienie barometryczne, temperatura otoczenia oraz związane z nią nasłonecznienie, siła wiatru, opady itp. „Mały oddech” temperaturowy jest związany z cykliczną zmianą temperatury w ciągu doby. Podwyższenie się temperatury powoduje wzrost prężności par i odparowanie pewnej części cieczy do przestrzeni 
nad jej powierzchnią oraz zwiększenie objętości mieszaniny parowo-powietrznej. Przyczynia się to do wzrostu ciśnienia w przestrzeni parowej zbiornika i wypchnięcia pewnej objętości tej mieszaniny na zewnątrz. Przy obniżeniu się temperatury następuje sytuacja odwrotna - wykroplenie się części par i zassanie powietrza z zewnątrz do przestrzeni parowej [6].

W wielu przypadkach możliwe jest znaczne ograniczenie emisji pochodzących z „małych oddechów” dzięki wykorzystaniu rozwiązań technicznych polegających na zastosowaniu systemów odgazowujących, których zadaniem jest zebranie oparów i skierowanie na urządzenia spalające/dopalające. W takie systemy odgazowania wyposażone są zbiorniki magazynowe metanolu, gazu płynnego LPG, a także niektóre zbiorniki ropy naftowej (w kopalniach i ekspedytach ropy naftowej).

Tak zwany „duży oddech” występuje podczas procesów napełniania zbiorników. Napływająca do zbiornika ciecz wypycha $z$ niego powietrze nasycone parami przeładowywanej substancji znacznie szybciej niż ma to miejsce podczas jej magazynowania. Wielkość emisji podczas przeładunku zależna jest od wielu czynników. Jednym z najważniejszych parametrów wpływających na wielkość emisji jest prężność par przeładowywanego i magazynowanego produktu; pozostałe to wydajność i temperatura przeładunku.

Proces przeładunku substancji z autocystern do zbiorników magazynowych (lub odwrotnie) odbywa się w sposób hermetyczny za pomocą stanowisk nalewczych. Stanowiska te mogą być wyposażone w suchozłącza wykorzystywane przy przeładunku LPG lub „wahadła gazowe” obniżające emisję zanieczyszczeń przy przelewaniu o około $95 \div 98 \%$.

Teoretycznie na terenie kopalni może wystąpić także emisja węglowodorów związana z oddychaniem autocystern podczas ich przejazdu. Jest ona jednak znikoma ze względu na zwykle krótki czas takiego przejazdu oraz wysokie nastawy zaworów ciśnieniowych stosowane w autocysternach. Straty związane $\mathrm{z}$ oddychaniem autocystern, określone na drodze pomiarowej, są niższe niż $0,001 \%$ objętości przechowywanej cieczy.

\section{Propozycja metod obliczania emisji}

\section{Emisja z magazynowania i przeladunku ropy naftowej}

W trakcie procesów napełniania zbiorników magazynowych, a także przelewania wydobytej kopaliny ze zbiorników do autocystern, przedostają się do powietrza węglowodory alifatyczne $i$ aromatyczne oraz w przypadku, gdy mamy do czynienia z ropą zasiarczoną - siarkowodór.

\section{Emisja podczas magazynowania}

Najbardziej wiarygodnym sposobem obliczania sumarycznej emisji węglowodorów ze zbiorników ropy naftowej jest metoda oparta na bilansie masowym produkcji i obrotu. Technika ta opracowana została na podstawie badań i prezentowana jest w publikacjach takich instytucji jak US EPA oraz API. Wymaga ona jednak bardzo szczegółowych danych dotyczących każdego z użytkowanych zbiorników, dlatego ma ograniczone zastosowanie.

Emisję ze zbiorników magazynowych można określić także na podstawie danych uzyskanych z ciągłego monitoringu emisji węglowodorów. Metoda pozwala na bardzo dokładne rozpoznanie i zidentyfikowanie strat powstałych przez odparowanie. Jest jednak bardzo kosztowna i przy dużej liczbie źródeł emisji (tj. zbiorników, stanowisk nalewczych itp.) praktycznie niewykonalna.

Nieco tańszym sposobem, aczkolwiek trudniejszym do zastosowania i niegwarantującym uzyskania wiarygodnych wyników, jest szacowanie wielkości emisji na podstawie pomiarów bezpośrednich prowadzonych systematycznie lub metodą losową.
Każda z przedstawionych powyżej metod, szczególnie w przypadku szacowania emisji dla dużej liczby obiektów, jest czasochłonna lub wymaga znacznych nakładów finansowych. Dlatego też w celu obliczenia emisji węglowodorów alifatycznych i aromatycznych proponuje się wykorzystanie metody wskaźnikowej przedstawionej w dokumencie EMEP/ EEA Air Pollutant Emission Inventory Guidebook - 2013, Oil - Exploration, Production, Transport (tablice 3-21 Uncontrolled VOC Emissions Factors for Crude Oil Rail Tank Cars and Tank Trucks) [4]. Wskaźnik ten określa łączną emisję lotnych związków organicznych zawartych w magazynowanej ropie.

Tablica 1. Wskaźnik emisji dla napełniania zbiornika magazynującego ropę naftową [4]

\begin{tabular}{|c|c|}
\hline Nazwa substancji & $\begin{array}{c}\text { Wskaźnik emisji } \\
{\left[\mathrm{g} / \mathrm{m}^{3}\right]}\end{array}$ \\
\hline LZO $^{*}$ & 580 \\
\hline
\end{tabular}

* Wskaźnik zamieszczony w opracowaniu dotyczy emisji całkowitej lotnych związków organicznych.

W celu doprecyzowania ilości poszczególnych substancji (węglowodorów aromatycznych i alifatycznych) emitowanych do powietrza można dodatkowo posłużyć się procentową zawartością tych składników w magazynowanej ropie dla konkretnych przypadków.

Wykorzystując powyższy wskaźnik, emisję substancji do powietrza z procesu magazynowania ropy naftowej można obliczyć za pomocą wzoru: 


$$
E=B \cdot w \cdot 10^{-3}
$$

gdzie:

$E$ - emisja poszczególnych substancji [kg],

$B$ - ilość przelewanej ropy naftowej $\left[\mathrm{m}^{3}\right]$,

$w$ - wskaźnik emisji na jednostkę przelewanej ropy naftowej $\left[\mathrm{g} / \mathrm{m}^{3}\right]$.

Dodatkowo podczas magazynowania i przeładunku zasiarczonej ropy naftowej będzie miała miejsce emisja siarkowodoru zawartego w kopalinie. Ponieważ stopień odparowania $\mathrm{H}_{2} \mathrm{~S}$ z ropy nie jest znany i zależy od wielu czynników, do obliczenia wielkości jego emisji należy posłużyć się założeniem, że do powietrza przedostaje się cała jego zawartość.

Biorąc pod uwagę powyższe, całkowitą emisję siarkowodoru można obliczyć, korzystając ze wzoru:

$$
E_{\mathrm{H} 2 \mathrm{~S}}=B \cdot C_{\mathrm{H} 2 \mathrm{~S}} \cdot 10^{-3}
$$

gdzie:

$E_{\mathrm{H} 2 \mathrm{~S}}$ - roczna emisja siarkowodoru $[\mathrm{kg}]$,

$B$-ilość przelewanej ropy naftowej $\left[\mathrm{m}^{3}\right]$,

$C_{\mathrm{H}_{2} \mathrm{~S}}$ - zawartość siarkowodoru w magazynowanej ropie $\left[\mathrm{g} / \mathrm{m}^{3}\right]$.

Informacje niezbędne do oszacowania całkowitej emisji $\mathrm{z}$ procesu magazynowania ropy naftowej $\mathrm{w}$ zbiornikach to:

- ilość magazynowanej w ciągu roku ropy naftowej $\left[\mathrm{m}^{3}\right]$,

- zawartość siarkowodoru w ropie $\left[\mathrm{g} / \mathrm{m}^{3}\right]$.

\section{Emisja z przeładunku}

Przy założeniu całkowitej emisji siarkowodoru podczas magazynowania ropy naftowej, w trakcie załadunku kopaliny na autocysterny emisja $\mathrm{H}_{2} \mathrm{~S}$ nie będzie miała miejsca.

Sposób obliczania emisji węglowodorów alifatycznych $i$ aromatycznych z procesu przeładunku ropy naftowej ze zbiorników magazynowych do autocystern jest taki sam jak dla magazynowania. Ilość uwalnianych substancji obliczymy, korzystając ze wzoru:

$$
E=B \cdot w \cdot 10^{-3}
$$

gdzie:

$E$ - emisja poszczególnych substancji $[\mathrm{kg}]$,

$B$ - ilość przelewanej ropy naftowej $\left[\mathrm{m}^{3}\right]$,

$w$ - wskaźnik emisji na jednostkę przelewanej ropy nafto-

wej $\left[\mathrm{g} / \mathrm{m}^{3}\right]$.

Wskaźnik emisji, z jakiego należy skorzystać w tym przypadku, przedstawiono w tablicy 2 .

Podczas przeładunku ropy naftowej istnieje możliwość zastosowania wahadła gazowego znacznie ograniczającego
Tablica 2. Wskaźnik emisji dla przeładunku ropy naftowej [4]

\begin{tabular}{|c|c|}
\hline Nazwa substancji & $\begin{array}{c}\text { Wskaźnik emisji } \\
{\left[\mathrm{g} / \mathrm{m}^{3}\right]}\end{array}$ \\
\hline LZO* $^{*}$ & 580 \\
\hline
\end{tabular}

* Wskaźnik zamieszczony w opracowaniu dotyczy emisji całkowitej lotnych związków organicznych.

emisję zanieczyszczeń do powietrza. Sprawność wahadła gazowego wynosi około $95 \div 98 \%$. W przypadku wykorzystania go należy odpowiednio przeliczyć otrzymane wyniki.

\section{Emisja z przeladunku metanolu}

Emisja metanolu do powietrza ma miejsce wyłącznie podczas procesu napełniania zbiornika („duży oddech”). W celu zmniejszenia zagrożenia stanowiska nalewcze w większości przypadków wyposażone są w wahadła gazowe obniżające emisję zanieczyszczeń o około $95 \div 98 \%$. Nie występuje natomiast emisja z zaworów ciśnieniowych zlokalizowanych na zbiornikach magazynowych (,małe oddechy"). W tym celu stosuje się systemy odprowadzające gromadzące się w zbiorniku gazy bezpośrednio do pochodni lub dopalacza.

Emisję metanolu do powietrza podczas napełniania zbiornika magazynowego można określić, korzystając ze wzoru:

$$
E=f B \cdot c \cdot Q
$$

gdzie:

$E$ - wielkość emisji metanolu [Mg/rok],

$f B$ - stopień nasycenia przestrzeni gazowej zbiornika, oznaczający stosunek osiągniętego stężenia metanolu w zbiorniku do stanu nasycenia [-],

$c$ - stopień nasycenia metanolem przestrzeni gazowej nad lustrem cieczy $\left[\mathrm{Mg} / \mathrm{m}^{3}\right]$,

$Q$ - przeładunek roczny substancji $\left[\mathrm{m}^{3} / \mathrm{rok}\right]$.

W celu obliczenia wielkości emisji przy napełnianiu zbiorników należy przyjąć następujące wartości:

$$
\begin{gathered}
f B=0,85, \\
c=0,000088\left[\mathrm{Mg} / \mathrm{m}^{3}\right] .
\end{gathered}
$$

\section{Emisja z przeładunku gazu płynnego LPG}

Proces technologiczny w instalacji tankowania gazu płynnego jest źródłem minimalnej emisji gazów będących składnikami gazu płynnego. Podczas czynności przepompowywania oraz magazynowania gazu płynnego nie następuje emisja par z uwagi na kompleksowe zhermetyzowanie tych procesów i szczelność instalacji. Emisja ma miejsce jedynie podczas rozłączenia węża autocysterny od złącza stacji po napełnieniu zbiornika magazynowego. 
W związku z tym proponowana metoda do wyliczania emisji uwzględnia emisję par gazu płynnego $\mathrm{z}$ całej długości węża po jego odłączeniu od zbiornika i autocysterny.

Emisję roczną par gazu płynnego należy określić, opierając się na rocznym obrocie paliwa, korzystając ze wzoru:

$$
E_{L P G}=\frac{V_{C}}{V_{P}} \cdot L_{W} \cdot V_{W} \cdot \rho
$$

gdzie:

$E_{L P G}-$ emisja par gazu płynnego $[\mathrm{kg} / \mathrm{rok}]$,

$V_{C}$ - roczna produkcja gazu $\mathrm{LPG}\left[\mathrm{m}^{3} / \mathrm{rok}\right]$,

$V_{P}$ - średnia objętość autocysterny $\left[\mathrm{m}^{3}\right]$,

$L_{W}$ - długość węża, w którym pozostaje gaz płynny [m],

$V_{W}$ - objętość węża $\left[\mathrm{m}^{2}\right]$,

$\rho-$ gęstość gazu płynnego (w fazie gazowej) $\left[\mathrm{kg} / \mathrm{m}^{3}\right]$.

$$
V_{W}=\frac{\pi \cdot d^{2}}{4}
$$

gdzie:

$d$-średnica węża [m].

\section{Emisja z magazynowania i przeladunku kondensatu (gazoliny)}

Emisja zanieczyszczeń do powietrza ma miejsce zarówno podczas magazynowania kondensatu (gazoliny), jak i w trakcie operacji związanych z napełnianiem lub przelewaniem go ze zbiorników do autocystern. W trakcie tych procesów do powietrza przedostają się węglowodory alifatyczne.

Podczas wyliczania wielkości emisji można przyjąć sposób proponowany przy obliczaniu emisji z magazynowania i przeładunku ropy naftowej, tj. wskaźnik emisji przedstawiony w dokumencie EMEP/EEA Air Pollutant Emission Inventory Guidebook - 2013, Oil - Exploration, Production, Transport (tablice 3-21 Uncontrolled VOC Emissions Factors for Crude Oil Rail Tank Cars And Tank Trucks) [4].

W skład LZO znajdujących się w kondensacie (gazolinie) wchodzą jedynie lekkie węglowodory alifatyczne. Zatem obliczona wielkość emisji będzie odpowiadała wielkości emisji węglowodorów alifatycznych.

Posługując się powyższym wskaźnikiem, emisję substancji do powietrza z procesu magazynowania i przeładunku kondensatu można obliczyć, korzystając ze wzoru:
Tablica 3. Wskaźniki emisji dla napełniania zbiornika magazynującego kondensat (gazolinę) [4]

\begin{tabular}{|c|c|}
\hline Nazwa substancji & $\begin{array}{c}\text { Wskaźnik emisji } \\
{\left[\mathrm{g} / \mathrm{m}^{3}\right]}\end{array}$ \\
\hline LZO $^{*}$ & 580 \\
\hline
\end{tabular}

* Wskaźnik zamieszczony w opracowaniu dotyczy emisji całkowitej lotnych związków organicznych.

$$
E=B \cdot w \cdot 10^{-3}
$$

gdzie:

$E$ - emisja poszczególnych substancji $[\mathrm{kg}]$,

$B$ - ilość przelewanego kondensatu $\left[\mathrm{m}^{3}\right]$,

$w$ - wskaźnik emisji na jednostkę przelewanego kondensatu $\left[\mathrm{g} / \mathrm{m}^{3}\right]$.

Podczas magazynowania i przeładunku kondensatu (gazoliny) nie występuje emisja siarkowodoru.

$\mathrm{W}$ trakcie przeładunku kondensatu (gazoliny) istnieje również możliwość zastosowania wahadła gazowego ograniczającego emisję zanieczyszczeń do powietrza o okoto $95 \div 98 \%$.

\section{Emisja z przetadunku oleju napędowego}

Podczas wykonywania otworów wiertniczych na terenie wiertni może być magazynowana znaczna ilość oleju napędowego wykorzystywanego przez agregaty napędzające urządzenie wiertnicze. Wielkość emisji par produktów naftowych z procesu napełniania zbiornika oleju napędowego należy określić z zależności:

$$
E=V \cdot k
$$

gdzie:

$V$ - szybkość napełniania $\left[\mathrm{m}^{3} / \mathrm{s}\right]$,

$k$-stężenie par oleju $\left[\mathrm{g} / \mathrm{m}^{3}\right]$ wynoszące $0,4 \div 1,3 \mathrm{~g} / \mathrm{m}^{3}$.

Ponieważ olej napędowy zawiera około $8 \%$ węglowodorów aromatycznych (war) i około $92 \%$ węglowodorów alifatycznych (wal), emisja węglowodorów aromatycznych i alifatycznych z magazynowania paliw wyniesie:

$$
\begin{aligned}
& E_{\mathrm{ONwar}}=V \cdot k \cdot 0,08 \\
& E_{\mathrm{ONwal}}=V \cdot k \cdot 0,92
\end{aligned}
$$

\section{Podsumowanie}

Metody obliczania wielkości emisji zanieczyszczeń do powietrza oraz wskaźniki w nich wykorzystywane nie zostały określone żadnym aktem prawnym. Dlatego też podmioty składające sprawozdania z tytułu wprowadzania do powietrza zanieczyszczeń mogą korzystać $\mathrm{z}$ wszystkich dostępnych wskaźników emisji oraz metod obliczeniowych.

Analizując możliwość zastosowania poszczególnych wskaźników i metod obliczania emisji, wzięto pod uwagę 
szeroką gamę urządzeń i instalacji stosowanych w kopalniach ropy naftowej i gazu ziemnego oraz dużą liczbę kopalń, dla których opracowanie indywidualnych wskaźników do stosowania dla wszystkich urządzeń/instalacji byłoby praktycznie niewykonalne.

Z tych samych powodów oparcie obliczeń emisji wyłącznie na pomiarach byłoby także trudne do wykonania, zwłaszcza z uwagi na koszty badań, którymi należałoby ob- jąć ogromną liczbę obiektów i urządzeń w skali kraju. Dlatego też najbardziej praktycznymi metodami określenia emisji są techniki oparte na wskaźnikach dostępnych w literaturze. Spośród metod przeanalizowanych w pracy, w artykule zostały wskazane te, które - biorąc pod uwagę różne aspekty - pozwalają na obliczenie wprowadzanych do powietrza zanieczyszczeń w sposób najbardziej przystępny, dając jednocześnie wyniki zbliżone do rzeczywistych.

Prosimy cytować jako: Nafta-Gaz 2017, nr 3, s. 187-192, DOI: 10.18668/NG.2017.03.06

Artykuł nadesłano do Redakcji 30.11.2016 r. Zatwierdzono do druku 20.01.2017 r.

Artykuł powstał na podstawie pracy statutowej pt.: Opracowanie metodologii obliczania wielkości emisji zorganizowanej zanieczyszczeń do powietrza z procesów magazynowania i przeładunku ropy naftowej, metanolu oraz plynnego gazu LPG towarzyszących eksploatacji złóż ropy naftowej i gazu ziemnego - praca INiG - PIB na zlecenie MNiSW; nr zlecenia: 0112/SN/16, nr archiwalny: DK-4100-177/16.

\section{Literatura}

[1] American Petroleum Institute (API). Compendium of Greenhouse Gas Emissions Methodologies for the Oil and Natural Gas Industry, 2009.

[2] American Petroleum Institute (API). Manual of Petroleum Measurement Standards Chapter 19.1 Evaporative Loss Measurement, Section 1-Evaporative Loss from Fixed-Roof Tanks, Fourth Edition, 2012.

[3] British Department for Environment, Food and Rural Affairs. Emission Factors Programme Task 7 - Review of Residential and Small-Scale Commercial Combustion Sources, 2003.

[4] EMEP/EEA Air Pollutant Emission Inventory Guidebook2013, Oil - Exploration, Production, Transport; Technical Guidance to Prepare National Emission Inventories, 2013.

[5] Krajowy Ośrodek Bilansowania i Zarządzania Emisjami (KOBIZE). Materiał dotyczący regulacji oraz wymagań w zakresie bilansowania emisji Niemetanowych Lotnych Związków Organicznych (NMLZO).

[6] Mazur M., Oleniacz R., Bogacki M.: Obliczanie emisji par węglowodorów z przemystu rafineryjnego. Inżynieria Środowiska 1996, t. 1, s. 105-116.

[7] Ministerstwo Środowiska. Dokument Referencyjny BAT dla ogólnych zasad monitoringu. Zintegrowane zapobieganie i ograniczanie zanieczyszczeń (IPPC), 2003.

[8] Niemczewska J., Zaleska-Bartosz J.: Wymagania dotyczace ewidencji i sprawozdawczości w zakresie emisji do powietrza zanieczyszczeń towarzyszacych eksploatacji złóż ropy naftowej i gazu ziemnego. Nafta-Gaz 2016, nr 10, s. 851-856, DOI: $10.18668 /$ NG.2016.10.10.

[9] Steczko K., Holewa J.: Strategia ochrony klimatu - inwentaryzacja emisji gazów cieplarnianych $w$ górnictwie naftowym. Nafta-Gaz 2009, nr 8, s. 597-600.

[10] U.S. Environmental Protection Agency (US EPA). Emission

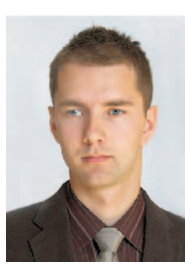

Mgr inż. Grzegorz KOŁODZIEJAK

Starszy specjalista inżynieryjno-techniczny w Zakładzie Ocen Środowiskowych.

Instytut Nafty i Gazu - Państwowy Instytut Badawczy ul. Lubicz 25A

31-503 Kraków

E-mail: grzegorz.kolodziejak@inig.pl
Factor Documentation for AP-42 Section 7.1 Organic Liquid Storage Tanks, Final Report. For U.S. Environmental Protection Agency Office of Air Quality Planning and Standards Emission Factor and Inventory Group, 2006.

[11] U.S. Environmental Protection Agency (US EPA). Emission Standards Reference Guide, 2013.

[12] U.S. Environmental Protection Agency (US EPA). Protocol for Equipment Leak Emission Estimates, 1995.

[13] U.S. Environmental Protection Agency (US EPA). User's Guide to Tanks; Storage Tank Emissions Calculation Software Version 4, 1999.

\section{Akty prawne i normatywne}

[14] Rozporzadzenie Ministra Środowiska z dnia 19 listopada 2008 r. w sprawie rodzajów wyników pomiarów prowadzonych $w$ zwiazku $z$ eksploatacja instalacji lub urzadzenia i innych danych oraz terminów $i$ sposobów ich prezentacji $(\mathrm{Dz} . \mathrm{U}$. z 2008 r. nr 215, poz. 1366)

[15] Rozporządzenie Ministra Środowiska z dnia 30 października 2014 r. w sprawie wymagań w zakresie prowadzenia pomiarów wielkości emisji oraz pomiarów ilości pobieranej wody (Dz. U. z 2014 r., poz. 1542).

[16] Rozporzadzenie Ministra Środowiska z dnia 4 listopada 2014 r. w sprawie standardów emisyjnych dla niektórych rodzajów instalacji, źródet spalania paliw oraz urzadzeń spalania lub wspótspalania odpadów (Dz. U. z 2014 r., poz. 1546, ze zm.).

[17] Ustawa z dnia 17 lipca 2009 r. o systemie zarzadzania emisjami gazów cieplarnianych i innych substancji (Dz. U. z 2015 r., poz. 2278).

[18] Ustawa z dnia 27 kwietnia 2001 r. Prawo ochrony środowiska (Dz. U. z 2016 r., poz. 672).

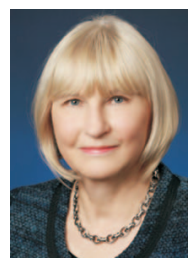

Mgr inż. Joanna ZALESKA-BARTOSZ

Starszy specjalista badawczo-techniczny w Zakładzie Ocen Środowiskowych.

Instytut Nafty i Gazu - Państwowy Instytut Badawczy ul. Lubicz 25 A

31-503 Kraków

E-mail: zaleska-bartosz@inig.pl 